Though a sufficient number of cultures have not yet been prepared from which to draw conclusions, attraction fields between pieces of adult tissue have not been found.

A total of about 1,500 cultures have been prepared, and among these some 150 definite fields have been observed (Fig. 2. 113-hr. culture, 19-day chick embryo intestine. Plasma Drew).

Whether the attraction fields observed by the authors bear any relation to the plasma fibrin strands produced by Doljanski and Roulet ${ }^{2}$ is not yet known. The experimental procedure employed by the latter investigators is quite different from our own in so far that they applied tension to plasma membranes and found cellular growths of explanted tissue oriented parallel to the fibrin strands. In our experiments, tension was not purposely applied to the plasma clot. We feel justified (for the present, at least) in ruling out any tension phenomena in the plasma clot being responsible for the observed fields. If it were a matter of tension, then it would seem reasonable to assume evidence for such in the cultures containing a dead and a living fragment of tissue. This was not found to be the case.

Further investigations are being continued in an effort to discover the true nature of these in vitro fields.

JoHn C. FARDon.

Gustave Brotzge.

Sister M. Kenneth Loeffler, O.P. JUANITA BREIT.

Institutum Divi Thomæ, Cincinnati, Ohio.

Sept. 20.

${ }^{1}$ Fardon, J. C., Sullivan, W. A., and Andrus, Sr. M. Basilia, Studies Inst. Divi' Thoma, vol. 2, N̂o. 2, 233 (1939).

'Doljanski,L., and Roulet, Fr., Roux's Arch. Entwicklungsmech. Organ., 131, 3, 512-531 (1934).

\section{Occurrence of Xylans in Marine Algæ}

WHEN the red alga, Rhodymenia palmata, commonly known as 'dilisk' or 'dulse', was immersed in dilute hydrochloric acid for about twenty-four hours, a viscid solution was obtained and, when this solution was poured into alcohol, a white solid was precipitated from it. This substance swelled up and dissolved when put into water. After purification by three precipitations with alcohol, the opalescent solution was cleared by repeated filtration. The substance now had a specific rotation of about -87 . On hydrolysis with dilute nitric acid, it yielded crystalline xylose.

This appears to be the first record of the isolation of a xylan from a marine alga, although, about seven years ago, Schmidt-Neilsen and Hammer ${ }^{1}$ noted the high yield of furfural obtainable from Rhodymenia palmata and estimated the pentosan content of the plant.

Another red alga, Dilsea edulis, also gives a highly viscid solution on treatment with dilute hydrochloric acid; but the substance obtained from this by precipitation with alcohol was not hydrolysed to xylose. This substance appears to be an ethereal sulphate similar to those already found in other marine algæ. It yields mucic acid on oxidation with nitric acid.
These substances are being further examined and the results of the investigations will be published elsewhere.

VINCENT C. Barry. Thomas Dillon.

Chemical Laboratory,

University College, Galway.

Oct. 19.

${ }^{1}$ Chem. Abs., 27, 5097 (1933).

\section{Average Gestation Period and $n \pi$}

IN a number of instances, average gestation periods seem to differ by a few hours only from $n \pi$ days. A few of the more remarkable approximations are :

\begin{tabular}{|c|c|c|c|l|}
\hline$n$ & $n \pi$ & $\begin{array}{c}\text { Average } \\
\text { gestation period } \\
\text { (days) }\end{array}$ & $\begin{array}{c}\text { No. of } \\
\text { preg. } \\
\text { nancies }\end{array}$ & \multicolumn{1}{|c|}{ Animal } \\
\hline 10 & $31 \cdot 416$ & $31 \cdot 41$ & 64 & English rabbit \\
36 & $113 \cdot 097$ & $113 \cdot 1 \pm 0 \cdot 12$ & 203 & Pig $^{2}$ \\
48 & $150 \cdot 796$ & $150 \cdot 8 \pm 0 \cdot 13$ & 195 & Karakul sheep \\
& & $150 \cdot 8 \pm 0 \cdot 19$ & 391 & Black Forest goat \\
49 & $153 \cdot 938$ & 154 & $?$ & Saanen goat \\
92 & $289 \cdot 026$ & $288 \cdot 9$ & 428 & Simmental cow \\
\hline
\end{tabular}

Further data are being studied.

$$
\begin{gathered}
\text { University Union, } \\
\text { Edinburgh. } \\
\text { Oct. } 10 .
\end{gathered}
$$

\section{J. H. KENNETH.}

${ }^{1}$ Rosahn, P. D., et al., Science, 79, 526 (1934).

'Husby, M., Meld. Norges Landbrukshoiskole (1933).

${ }^{3}$ Baranov, A. G., Usp. zootech. Nauk, 5 (1937).

' Hinterthür, E., Züchtungskunde, 8 (1933).

${ }^{\circ}$ Kiesling, A., Z. Zilchtg., 27 (1933).

' Indermühle, Schweiz. Arch. Tierheilk. (1911).

\section{Psychology and Camouflage}

Perusal of the interesting article by "J. S. H." on camouflage in NATURE of October 12 leaves one rather wondering why the technical staff of the organization described should include artists, engineers, architects, chemists, physicists, photographers, and a botanist, while apparently not a single psychologist is connected with this organization. Surely the problems of camouflage are problems in perception, perhaps the most advanced field of psychological study. The fundamental laws on which camouflage must be based are partly psychological (the Liebmann law, for example, which deals with the relative differentiation due to colour and brightness, or the Wertheimer laws of organization), and it seems reasonable to ask why no use is being made of the vast amount of knowledge available.

\section{Howitt Close,}

Howitt Road,

London, N.W.3. Oet. 14. 